\title{
Results of serological tests for syphilis among Gurkhas and other high risk groups
}

\author{
R N THIN* AND C M J O'RORKE† \\ From the Departments of Genitourinary Medicine, *St Thomas's Hospital, London and + British Medical \\ Hospital Munster, British Army of the Rhine, West Germany
}

SUMMARY Serological tests for syphilis gave more positive results in serving Gurkha (Nepali) soldiers from west Nepal than in those from east Nepal or in Gurkha recruits. The soldiers had served from four to 11 years. The source of their infection was not clear. Positive results were rather less common in black patients born in the tropics attending a genitourinary medicine in London and were similar to findings in blood donors in the West Indies. British born male patients attending a genitourinary medicine department in London had a much lower prevalence. Malay and Nepali women attending an antenatal clinic in Singapore had a higher prevalence of positive serological results than women attending an antenatal clinic in London. Nepalis, Malays, and black people born in the tropics continue to require serological screening.

\section{Introduction}

Thin reported that among servicemen in Singapore syphilis was more common in Gurkha (Nepali) soldiers than in British soldiers and more prevalent among British servicemen in Singapore than among men in Britain. ${ }^{1}$ Gurkhas were examined in greater detail in another paper, which reported that there were $3 \cdot 5$ times more cases of syphilis among Gurkhas than among British soldiers. ${ }^{2}$ Just over half the infections in Gurkhas were acquired in Nepal.

This observation prompted serological studies among Gurkhas, and data were collected in Britain and examined for comparison.

\section{Subjects and methods}

Blood was collected during 1974 from Gurkha recruits in Hong Kong and from serving Gurkha soldiers stationed in Britain. Serum was separated, and each sample was divided into two aliquots and stored at $-20^{\circ} \mathrm{C}$. Samples were transported to London packed in frozen carbon dioxide at $-78 \cdot 5^{\circ} \mathrm{C}$. Those from Hong Kong came on a direct flight. One aliquot from each sample was examined at the Royal Army Medical College by the cardiolipin Wasserman reaction (CWR), the Venereal Diseases Research Laboratory (VDRL) test, the Reiter protein complement fixation (RPCF) test, and the fluorescent

Address for reprints: Dr R N Thin, Department of Genitourinary Medicine, St Thomas's Hospital, London SE1 7EH

Accepted for publication 8 April 1984 treponemal antibody absorbed (FTA-ABS) test. When any sample gave a positive result, the corresponding aliquot was examined at St Thomas's Hospital by the VDRL test, the Treponema pallidum haemagglutination assay (TPHA), and the FTA-ABS IgG and IgM tests. ${ }^{34}$

For comparison, we reviewed the serological results of male British born whites, British born blacks, and blacks born in the tropics attending the genitourinary department at St Thomas's Hospital for the first time in the first quarter of 1982. Samples of their serum were examined by the VDRL, TPHA and FTA-ABS IgG and IgM tests.

\section{Results}

Samples were taken from 635 Gurkha recruits (mean age 17), but satisfactory results were obtained from only 608. Samples were collected from 301 serving Gurkha soldiers (aged 21-28), and satisfactory results were obtained from 300 . They had served from four to 11 years. The VDRL test gave 18 positive results at the Royal Army Medical College and 13 at St Thomas's Hospital. Of the discrepant VDRL results, three were reported negative at one laboratory and reacted to only undiluted serum at the other laboratory, and two were negative at one laboratory and reactive at a dilution of $1 / 2$ at the other. The FTA-ABS test gave 20 positive results at the Royal Army Medical College and 19 positive results to the FTA-ABS IgG test at St Thomas's Hospital. The TPHA test gave 18 positive results at St Thomas's Hospital. 
We tested 652 white British born men (aged 14-80) who attended the genitourinary medicine department at St Thomas' Hospital for the first time between 1 January and 31 March 1982 . Six gave positive results to the VDRL test (of which one was a biological false positive result as TPHA and FTA-ABS tests gave repeatedly negative results) and 14 gave positive TPHA results. Of 158 British born black men who attended (aged 15 to 43), none had a positive VDRL result and two had positive TPHA results, which indicated old treated disease, probably acquired venereal syphilis. Of 293 black patients born in the tropics who attended (aged 17 to 64), 16 had positive VDRL results and 57 had positive TPHA results. There were no positive VDRL results in these blacks under 29 years old and only four positive TPHA results in those aged 21 to 28 . All other positive results were in older men.

Table I shows the findings in the patients matched by age to the Gurkha recruits and soldiers. The soldiers from west Nepal had noticeably more positive results than those from east Nepal or the patients.

TABLE I Serological test results in patients and Gurkha soldiers and recruits

\begin{tabular}{|c|c|c|c|c|c|}
\hline \multirow[b]{2}{*}{ Group } & \multirow[b]{2}{*}{ No } & \multirow{2}{*}{$\begin{array}{l}\text { Age range } \\
\text { (years) }\end{array}$} & \multicolumn{2}{|c|}{$\begin{array}{l}\text { Positive* } \\
\text { results to }\end{array}$} & \multirow{2}{*}{$\begin{array}{l}\text { Percent } \\
\text { positive }\end{array}$} \\
\hline & & & $V D R L$ & TPHA & \\
\hline $\begin{array}{l}\text { Gurkha recruits } \\
\text { British born whites } \\
\text { British born blacks } \\
\text { Tropics born blacks }\end{array}$ & $\begin{array}{r}608 \\
99 \\
64 \\
11\end{array}$ & $\begin{array}{l}16-18 \\
14-19 \\
15-19 \\
17-19\end{array}$ & $\begin{array}{l}5 \\
1 \\
0 \\
0\end{array}$ & $\begin{array}{l}6 \\
1 \\
2 \\
0\end{array}$ & $\begin{array}{l}1 \cdot 0 \\
1 \cdot 0 \\
3 \cdot 1 \\
0\end{array}$ \\
\hline $\begin{array}{l}\text { Gurkha soldiers E† } \\
\text { Gurkha soldiers W‡ } \\
\text { British born whites } \\
\text { British born blacks } \\
\text { Tropics born blacks }\end{array}$ & $\begin{array}{r}152 \\
148 \\
261 \\
69 \\
104\end{array}$ & $\begin{array}{l}21-28 \\
21-28 \\
21-28 \\
21-28 \\
21-28\end{array}$ & $\begin{array}{l}1 \\
7 \\
0 \\
0 \\
0\end{array}$ & $\begin{array}{r}2 \\
10 \\
0 \\
0 \\
4\end{array}$ & $\begin{array}{l}1 \cdot 3 \\
6 \cdot 8 \\
0 \\
0 \\
3 \cdot 8\end{array}$ \\
\hline
\end{tabular}

- St Thomas's Hospital results; VDRL = Venereal Disease Research Laboratory test; TPHA = Treponema pallidum haemagglutination assay.

${ }^{\dagger}$ Born in east Nepal; $₹$ Born in west Nepal.

\section{Discussion}

Agreement between the two laboratories was satisfactory. There was good agreement for VDRL results with titres of $1 / 4$ and higher; discrepant results all had low titres. Agreement between FTAABS results at the Royal Army Medical College and the FTA-ABS IgG test, a closely corresponding test, was good and so was agreement between TPHA and FTA-ABS results. For simplicity and to allow comparisons, the tables present the VDRL and TPHA results from St Thomas's Hospital.

A notable feature of the results is the high prevalence of positive findings among older blacks born in the tropics, which presumably reflects the higher prevalence of syphilis and yaws there. The two positive TPHA results among British born blacks could have occurred by chance in this sample, especially as they were in the younger age group. On the whole the findings among the British born blacks were similar to those of the British born whites, as was expected.

The findings show that Gurkha recruits, selected healthy young men, had similar serological test results to the other younger men (table I). The two positive TPHA results among the British born blacks indicated old inactive disease and were thought to be due to treated congenital or acquired venereal syphilis. The findings among the Gurkha recruits indicated some with old and some with new disease. This may have been due to congenital or acquired venereal syphilis. The prevalence does not support a previous suggestion that there may be endemic syphilis in Nepal. ${ }^{2}$

The findings among the older Gurkhas showed more positive results among soldiers from west Nepal than from east Nepal, and this is in keeping with a previous suggestion. ${ }^{5}$ Reasons for this are not clear, and possibilities include: (a) higher prevalence of venereal syphilis in west Nepal; (b) higher prevalence of congenital or endemic syphilis in west Nepal, though this is less likely than (a) in view of the low rates in recruits; (c) greater exposure to venereal syphilis when travelling home for long leave; or (d) greater exposure to venereal syphilis during military service.

TABLE II Comparison of serological test results with those in other studies

\begin{tabular}{|c|c|c|}
\hline Subjects & Tests & $\begin{array}{l}\text { Percentage } \\
\text { positive }\end{array}$ \\
\hline $\begin{array}{l}\text { Gurkha recruits } \\
\text { Gurhka soldiers (east Nepal) } \\
\text { Gurhka soldiers (west Nepal) } \\
\text { British born patients aged 21-28 } \\
\text { Tropics born blacks aged 21-28 }\end{array}$ & $\begin{array}{l}\text { VDRL \& TPHA } \\
\text { VDRL \& TPHA } \\
\text { VDRL \& TPHA } \\
\text { VDRL \& TPHA } \\
\text { VDRL \& TPHA }\end{array}$ & $\begin{array}{l}1 \cdot 0 \\
1 \cdot 3 \\
6 \cdot 8 \\
0 \\
3 \cdot 8\end{array}$ \\
\hline $\begin{array}{l}\text { Blood donors } 6 \text { in: } \\
\text { Adelaide } \\
\text { France } \\
\text { Martinique (French West Indies) } \\
\text { Guadeloupe } \\
\text { Barbados } \\
\text { Jamaica }\end{array}$ & $\begin{array}{l}\text { FTA-ABS } \\
\text { TPHA } \\
\text { TPHA } \\
\text { TPHA } \\
\text { TPHA } \\
\text { TPHA }\end{array}$ & $\begin{array}{l}0 \cdot 003 \\
0 \cdot 04 \\
2 \cdot 75 \\
2 \cdot 85 \\
3 \cdot 1 \\
4 \cdot 8\end{array}$ \\
\hline $\begin{array}{l}\text { Antenatal clinics in: } \\
\text { Singapore* Nepalis } \\
\text { Malays } \\
\text { Londont }\end{array}$ & $\begin{array}{l}\text { VDRL } \\
\text { VDRL } \\
\text { VDRL \& TPHA }\end{array}$ & $\begin{array}{l}4 \cdot 4 \\
5 \cdot 3 \\
0 \cdot 8\end{array}$ \\
\hline Nepalis in Nepal5 & VDRL & $0 \cdot 1$ \\
\hline
\end{tabular}

VDRL = Venereal Disease Research Laboratory test.

TPHA = Treponema pallidum haemagglutionation assay. FTA-ABS = Fluorescent treponemal antibody absorbed test

* O'Rorke, personal communication; 1309 Nepalis and 985 Malays. $\uparrow$ Wasley, personal communication; 1345 women. 
In table II the findings among the recruits and soldiers and the 21-28 year old patients are compared with West Indian blood donors, ${ }^{6}$ Nepali and Malay women attending the antenatal clinic at the British Medical Hospital, Singapore during 1966-8(O'Rorke, personal communication), women attending the antenatal clinic at St Thomas's Hospital during the last quarter of 1982 (Wasley, personal communication), and Nepalis in Nepal. 5 The blacks born in the tropics attending St Thomas's Hospital had results similar to those among blood donors in Barbados and Jamaica. That might be expected as many of the black patients came from Jamaica, though higher prevalence might be expected among our high risk patients than among blood donors. Again the highest prevalence of positive results was among Gurkha soldiers from west Nepal.

Gurkha soldiers from west Nepal, and probably their wives, are a high risk group for treponemal disease. Of more general interest it is apparent that older blacks born in the tropics, including West Indians from islands not normally represented in Britain, are at higher risk than British born subjects. Malay women attending antenatal clinics, and probably their husbands, are also probably at high risk. Serological screening of these groups remains important, and it must be remembered that yaws has recrudesced in various foci in the tropics. ${ }^{7}$

We thank Dr Pauline O'Neill, Dr J C Taylor, Mr D Goode, and $\mathrm{Mr} \mathrm{G}$ Wasley for undertaking the serological tests.

\section{References}

1. Thin RNT. Venereology in the British Army in 1980. British Journal of Venereal Diseases 1982; 48: 542-4.

2. Thin RNT. Syphilis among Gurkhas from Nepal. British Journal of Venereal Diseases 1972; 48: 189-93.

3. O'Neill $P$, Nicol CS. IgM class antibody in treated and untreated syphilis. British Journal of Venereal Diseases 1972; 48:460-3.

4. O'Neill P, Warner RW, Nicol CS. Treponema pallidum haemagglutination assay in the routine serodiagnosis of treponemal disease. British Journal of Venereal Diseases 1973;49:427-31.

5. Worth RM, Shah NK. Nepal Health Survey 1965-66. Honolulu: University of Hawaii Press, 1969:60.

6. Mornex JF, Monplaisir N. Positive serological test for syphilis in West Indies. Transfusion 1981;21:230.

7. Anonymous. Endemic treponematoses in the 1980s. Lancet 1983; ii:551-2. 